Article

\title{
New Triterpenes from Maytenus robusta: Structural Elucidation Based on NMR Experimental Data and Theoretical Calculations
}

Grasiely F. Sousa ${ }^{1}$, Lucienir P. Duarte ${ }^{1, *}$, Antônio F. C. Alcântara ${ }^{1}$, Grácia D. F. Silva ${ }^{1}$, Sidney A. Vieira-Filho ${ }^{2}$, Roqueline R. Silva ${ }^{1}$, Djalma M. Oliveira ${ }^{3}$ and Jacqueline A. Takahashi ${ }^{1}$

1 Departamento de Química, Instituto de Ciências Exatas, Universidade Federal de Minas Gerais, 31270-901, Belo Horizonte, MG, Brazil

2 Escola de Farmácia, Universidade Federal de Ouro Preto, 35400-000, Ouro Preto, MG, Brazil

3 Departamento de Química e Exatas, Universidade Estadual do Sudoeste da Bahia, 45206-191, Jequié, BA, Brazil

* Author to whom correspondence should be addressed; E-Mail: lupadu@netuno.lcc.ufmg.br; Tel.: +55-31-3409-5722; Fax: +55-31-3409-5700.

Received: 12 September 2012; in revised form: 5 November 2012 / Accepted: 7 November 2012 / Published: 12 November 2012

Abstract: Leaves of Maytenus robusta (Celastraceae) were subjected to phytochemical investigation mainly directed at the isolation of pentacyclic triterpenes. The compounds friedelin (1), $\beta$-friedelinol (2), 3-oxo-21 $\beta$ - $H$-hop-22(29)-ene (7), 3,4-seco-friedelan-3,11 $\beta$ olide (8), $3 \beta$-hydroxy-21 $\beta$ - $H$-hop-22(29)-ene (9), 3,4-seco-21 $\beta$ - $H$-hop-22(29)-en-3-oic acid (10), 3,4-seco-friedelan-3-oic acid (11), and sitosterol were identified in the hexane extract of $M$. robusta leaves. Compounds $\mathbf{8}$ and $\mathbf{9}$ are described herein for the first time. The structure and stereochemistry of both compounds were experimentally established by IR, HRLC-MS, and 1D $\left({ }^{1} \mathrm{H},{ }^{13} \mathrm{C}\right.$, and DEPT 135) and 2D (HSQC, HMBC and COSY) NMR data and supported by correlations with carbon chemical shifts calculated using the DFT method (BLYP/6-31G* level). Compounds $\mathbf{7}$ and $\mathbf{1 0}$ are also described for the first time, and their chemical structures were established by comparison with NMR data of similar structures described in the literature and correlations with BLYP/6-31G* calculated carbon chemical shifts. Compound 9, a mixture of $\mathbf{1 1}$ and sitosterol, and $3 \beta, 11 \beta$-dihydroxyfriedelane (4) were evaluated by the Ellman's method and all these compounds showed acethylcholinesterase inhibitory properties. 
Keywords: Maytenus robusta; pentacyclic triterpenes; NMR; DFT calculations; acetylcholinesterase inhibitory activity

\section{Introduction}

Secondary metabolites are isolated from plants and animals, and many of them have been used as sources of derivatives with a large spectrum of biological activities [1], including effects in the treatment of Alzheimer's disease (AD). AD is a progressive neurodegenerative disorder characterized by a decline in memory and cognitive abilities. About 34 million people around the World have AD, being the major cause of dementia in elderly people [2]. Acetylcholinesterase (AChE) inhibitors are a group of drugs frequently investigated for the symptomatic treatment of $\mathrm{AD}$ [3]. Alternatively, the literature also describes some relationships between pentacyclic triterpenes and treatments for AD [4-7].

Some biologically active alkaloids, phenolic compounds, and terpenes have been isolated from some species of Maytenus (Celastraceae) [8-14]. The triterpenes friedelin (3-oxofriedelane; 1), $\beta$-friedelinol (3 $\beta$-hydroxyfriedelane; 2 ), and 3,15-dioxo-21 $\alpha$-hydroxyfriedelane (3) were isolated from the leaves of Maytenus robusta [15-17] (Figure 1). Moreover, we recently studied a white precipitate obtained from the hexane extract of the leaves of $M$. robusta, resulting in isolation and identification of a new triterpene 3 $\beta, 11 \beta$-dihydroxyfriedelane (4) and the known triterpenes 1, 2, 3-oxo-29hydroxyfriedelane (5), and 3-oxo-11 $\beta$-hydroxyfriedelane (6) [18] (Figure 1).

Figure 1. Chemical structure of the triterpenes $\mathbf{1}$ to $\mathbf{6}$ previously isolated from the leaves of M. robusta.
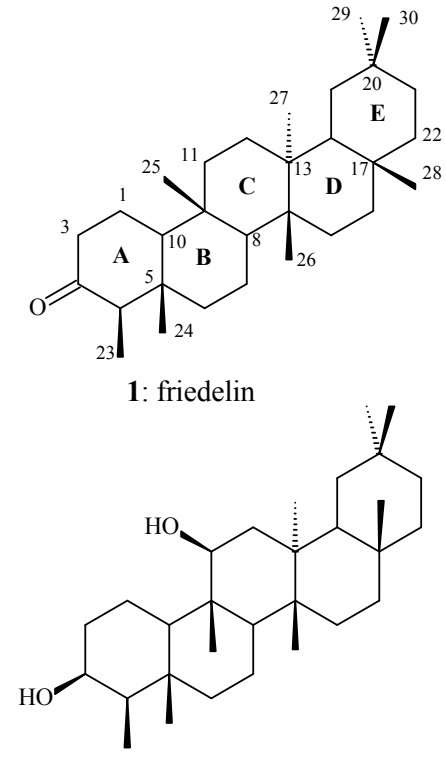

4: $3 \beta, 11 \beta$-dihydroxyfriedelane

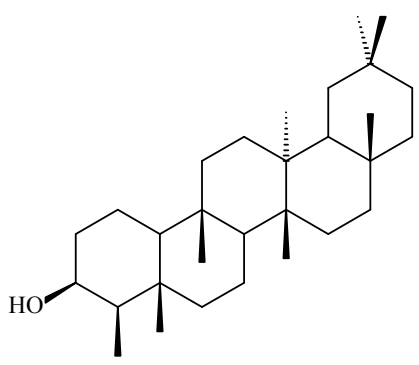

2: friedelinol

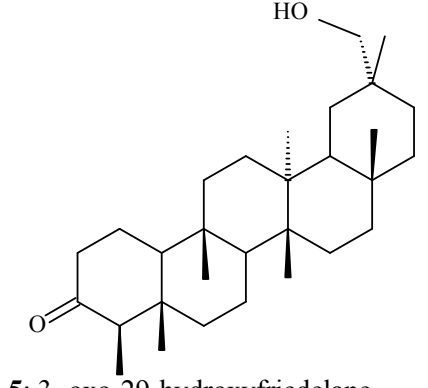

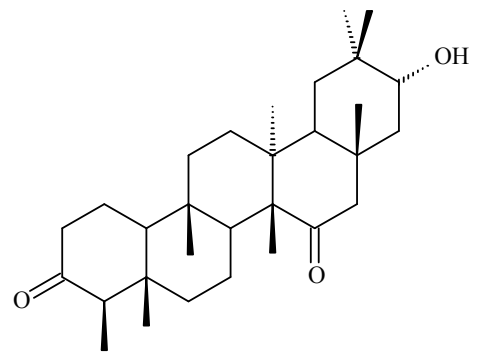

3: 3,15-dioxo-21 $\alpha$-hydroxyfriedelane

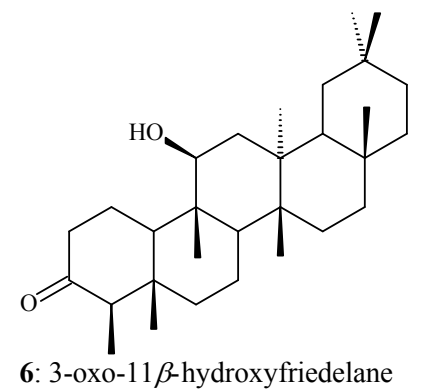

Species of the genus Maytenus are used in the traditional Brazilian medicine for the treatment of gastric ulcers [19], inflammations, and diarrhea [20], as antimicrobial [21,22], antitumor [23,24], insecticidal agents [25], and for other purposes [14,20]. The antiulcerogenic and antinociceptive 
activities of $M$. robusta were previously investigated [16,17], but the AChE inhibitory activity of the triterpenes isolated from the species of Maytenus has not been tested to date.

Therefore, the present work describes a phytochemical study of the leaves of M. robusta that was directed to the isolation of triterpenes and analysis of their AChE inhibitory activity. The leaf hexane extract of $M$. robusta provided the triterpenes 1, 2, 3-oxo-21 $\beta$ - $H$-hop-22(29)-ene (7), 3,4-secofriedelan-3,11 $\beta$-olide (8), 3 $\beta$-hydroxy-21 $\beta$-H-hop-22(29)-ene (9), 3,4-seco-21 $\beta$-H-hop-22(29)-en-3-oic acid (10), and 3,4-seco-friedelan-3-oic acid (11) and the steroid sitosterol (Figure 2).

Figure 2. Chemical structure of triterpenes isolated from the leaves of M. robusta (compounds 7 to 11), including similar chemical structures of triterpenes (compounds $\mathbf{1 2}$ to 15) with NMR data described in the literature.

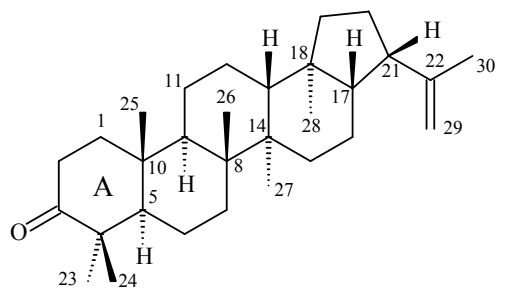

7: 3-oxo-21 $\beta$-H-hop-22(29)-ene

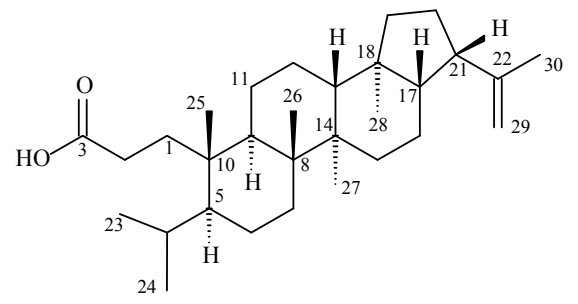

10: 3,4-seco-21 $\beta$-H-hop-22(29)-en-3-oic acid

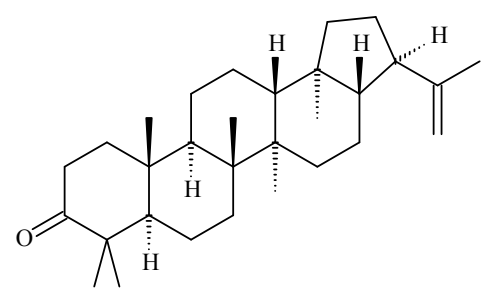

13: 3-oxo-21 $\alpha$-H-hop-22(29)-ene

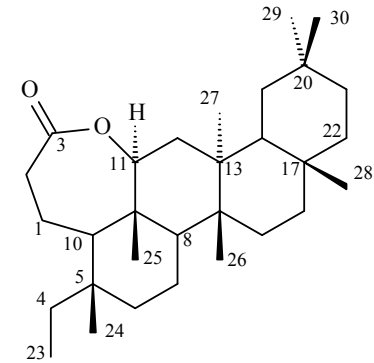

8: 3,4-seco-friedelan-3,11 $\beta$-olide

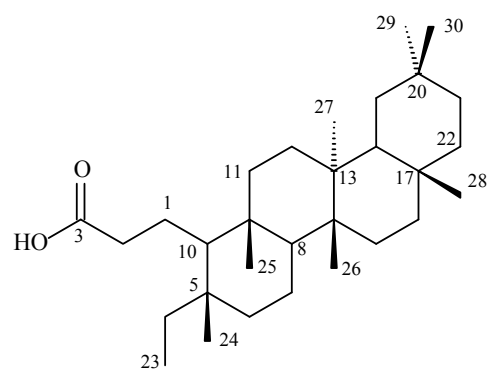

11: 3,4-seco-friedelan-3-oic acid

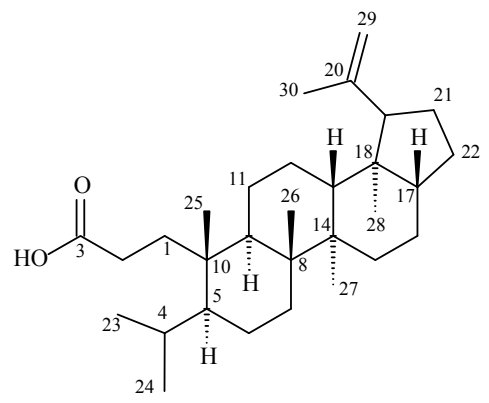

14: 3,4-seco-lup-20(29)-en-3-oic acid

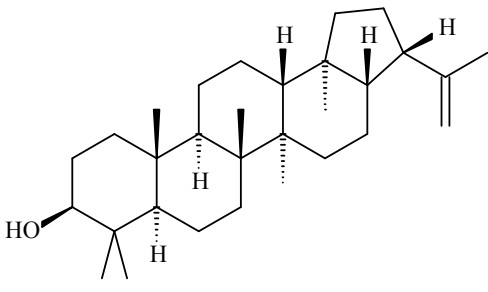

9: $3 \beta$-hydroxy-21 $\beta$ - $H$-hop-22(29)-ene

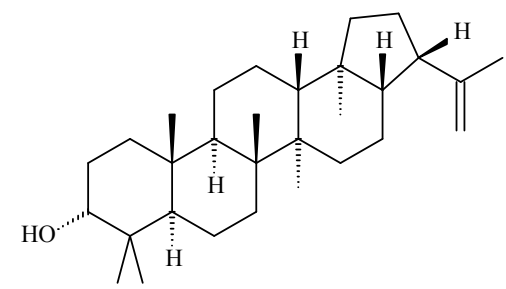

12: $3 \alpha$-hydroxy-21 $\beta$-H-hop-22(29)-ene

Triterpenes 8 and 9 are described for the first time in the literature. Their structure and stereochemistry were deduced from experimental IR, HRLC-MS, and $1 \mathrm{D}\left({ }^{1} \mathrm{H},{ }^{13} \mathrm{C}\right.$, and DEPT 135) and 2D (HSQC, HMBC, and COSY) NMR analyses and theoretical methodology based on carbon chemical shifts calculated using the BLYP/6-31G* level of theory. 
Compounds $\mathbf{7}$ and $\mathbf{1 0}$ are also new in the literature and were isolated as binary mixtures with $\mathbf{1}$ and $\mathbf{1 1}$, respectively (Figure 2). The chemical structure of $\mathbf{7}$ and $\mathbf{1 0}$ were established based on 1D NMR analyses, comparison with the NMR spectral data of the terpenes $3 \alpha$-hydroxy-21 $\beta$ - $H$-hop-22(29)-ene (12) [26], 3-oxo-21 $\alpha$-H-hop-22(29)-ene (13) [27], 3,4-seco-lup-20(29)-en-3-oic acid (14) [28], and 21 $\beta$-H-hop-22(29)-ene (15) [26] (Figure 2), and correlations with carbon chemical shifts calculated using BLYP/6-31G*. The chemical structure of compounds 1, 2, 11 and sitosterol were based on comparisons with the NMR data available in the literature. The triterpenes 4, 9, and 11 were submitted to the Ellman's bioassay [29,30] and exhibited AChE inhibitory properties.

\section{Results and Discussion}

\subsection{Structural Analysis}

\subsubsection{Compounds 1 and 7}

The hexane extract (HE) fractions eluted with 9:1 hexane-chloroform provided a white solid. The IR spectrum of this solid shows two intense absorptions at 1,714 and $1,701 \mathrm{~cm}^{-1}$ which are attributed to carbonyl groups. The ${ }^{13} \mathrm{C}-\mathrm{NMR}$ spectrum shows two groups of 30 signals, each with significant differences in intensity. The ${ }^{13} \mathrm{C}$-NMR data of the group of high-intensity signals (named triterpene 1) present a signal at $\delta_{\mathrm{C}} 213.2$ which is characteristic of a carbonyl carbon. The NMR data are similar to the corresponding ones described in the literature for the triterpene friedelin [31]. In turn, the ${ }^{13} \mathrm{C}$-NMR data of the group of low-intensity signals (named triterpene 7) present a signal at $\delta_{\mathrm{C}} 218.2$ which is also characteristic of a carbonyl carbon. Two other signals at $\delta_{\mathrm{C}} 148.6$ and 110.1 (non-hydrogenated and methylene carbon atoms, respectively) are characteristic of alkenyl carbon atoms. The ${ }^{1} \mathrm{H}-\mathrm{NMR}$ data show a signal at $\delta_{\mathrm{H}} 4.78$ (integrated for two hydrogen atoms) which is also characteristic of an alkenyl group. These signals are in agreement with a hopane-type skeleton containing a carbonyl carbon. The ${ }^{13} \mathrm{C}-\mathrm{NMR}$ data of 7 were compared with the hopane-type skeleton data compiled in the literature for $\mathbf{1 2}$ and $\mathbf{1 3}$ (see Figure 2 and Table 1). Triterpene 7 only differs in relation to the substituent at C-3 of the ring A of $\mathbf{1 2}$ and the stereochemistry of the C-21 in the ring E of 13. In fact, the NMR data of $\mathrm{C}-1$ to $\mathrm{C}-15$ of $\mathbf{1 3}$ are very similar to the corresponding data of $\mathbf{7}$. On the other hand, the NMR data of C-14 to C-30 (except for C-23 and C-24) of 12 are very similar to the corresponding data of 7 . As result, it can be proposed that the chemical structure of 7 is a combination of the rings $\mathrm{A}-\mathrm{C}$ of $\mathbf{1 3}$ and rings $\mathrm{C}-\mathrm{E}$ of $\mathbf{1 2}$. The chemical structure of $\mathbf{7}$ is thus in agreement with that of the compound 3-oxo-21 $\beta$-H-hop-22(29)-ene, a triterpene which was not yet described in the literature. Moreover, the intensity and integration of the carbonyl carbon atom signals based on quantitative ${ }^{13} \mathrm{C}-\mathrm{NMR}$ analysis indicates a mixture 2:1 of compounds $\mathbf{1}$ and 7 , respectively. BLYP/6-31G* geometry optimization calculations were carried out for 7 with a starting geometry based on the stereochemistry proposed to 3-oxo-21 $\beta$ - $H$-hop-22(29)-ene (see Figure 2 ). The most stable optimized geometry of 7 ( $E=-1246.52767272$ a.u.) presents rings $\mathrm{A}-\mathrm{D}$ in the chair conformation and ring $\mathrm{E}$ in the envelope one. Moreover, the C-29 of the allyl group is positioned close to the methyl group at C-28. Carbon chemical shift calculations were carried out on the optimized geometry of 7 at the same level of theory. Correlations between calculated and experimental ${ }^{13} \mathrm{C}-\mathrm{NMR}$ carbon chemical shift values of the data of 7 (Table 1) provided high correlation coefficient $\left(R^{2}=0.99330\right)$ and slope of the $R^{2}$ 
curve $(\alpha=0.91728)$. These theoretical results are also in agreement with the stereochemistry of 3-oxo21 $\beta$ - $H$-hop-22(29)-ene proposed for 7.

Table 1. ${ }^{13} \mathrm{C}-\mathrm{NMR}$ data of triterpene 7, compared with the corresponding data described in the literature for 12 [26] and $\mathbf{1 3}$ [27], and ${ }^{13} \mathrm{C}-\mathrm{NMR}$ data of triterpene 10, compared with the corresponding data described in the literature for 14 [28] and 15 [26].

\begin{tabular}{|c|c|c|c|c|c|c|}
\hline \multirow[t]{2}{*}{ Carbon } & \multicolumn{6}{|c|}{ Compound $/ \delta_{\mathrm{C}}$} \\
\hline & 7 & 12 & 13 & 10 & 14 & 15 \\
\hline 1 & 39.6 & 33.2 & 39.6 & 33.8 & 33.8 & 40.4 \\
\hline 2 & 34.2 & 25.4 & 34.2 & 28.4 & 28.3 & 18.7 \\
\hline 3 & 218.2 & 76.3 & 217.9 & 180.1 & 180.6 & 42.1 \\
\hline 4 & 47.4 & 37.2 & 47.4 & 25.4 & 25.9 & 33.3 \\
\hline 5 & 54.9 & 50.1 & 54.9 & 40.7 & 40.7 & 56.1 \\
\hline 6 & 19.7 & 18.3 & 19.8 & 18.3 & 25.0 & 18.7 \\
\hline 7 & 33.7 & 33.2 & 32.7 & 32.0 & 29.6 & 33.3 \\
\hline 8 & 41.6 & 41.9 & 41.6 & 40.0 & 40.5 & 42.1 \\
\hline 9 & 49.6 & 49.5 & 49.7 & 47.2 & 47.1 & 50.4 \\
\hline 10 & 36.8 & 37.5 & 36.8 & 41.5 & 39.1 & 37.5 \\
\hline 11 & 21.6 & 20.9 & 21.6 & 21.7 & 21.5 & 20.9 \\
\hline 12 & 23.9 & 23.9 & 23.9 & 24.0 & 24.9 & 24.0 \\
\hline 13 & 49.6 & 48.9 & 48.8 & 49.6 & 38.0 & 49.5 \\
\hline 14 & 42.1 & 42.1 & 42.3 & 42.5 & 42.9 & 41.9 \\
\hline 15 & 32.6 & 33.6 & 32.7 & 32.7 & 27.3 & 33.6 \\
\hline 16 & 21.6 & 21.6 & 20.8 & 21.8 & 35.4 & 21.6 \\
\hline 17 & 54.9 & 54.9 & 53.9 & 54.9 & 43.1 & 54.9 \\
\hline 18 & 44.7 & 44.7 & 44.2 & 44.8 & 48.1 & 44.8 \\
\hline 19 & 41.9 & 41.9 & 40.2 & 42.0 & 47.8 & 41.9 \\
\hline 20 & 27.3 & 27.4 & 27.8 & 27.4 & 150.6 & 27.4 \\
\hline 21 & 46.4 & 46.5 & 47.9 & 46.5 & 29.7 & 46.5 \\
\hline 22 & 148.6 & 148.7 & 148.0 & 148.7 & 39.8 & 148.7 \\
\hline 23 & 26.6 & 28.6 & 26.6 & 19.4 & 19.5 & 33.4 \\
\hline 24 & 21.1 & 22.5 & 21.1 & 18.8 & 18.7 & 21.6 \\
\hline 25 & 15.7 & 15.7 & 15.7 & 16.5 & 15.8 & 15.9 \\
\hline 26 & 16.4 & 16.6 & 16.5 & 24.8 & 20.0 & 16.7 \\
\hline 27 & 16.6 & 16.8 & 16.5 & 16.5 & 14.3 & 16.7 \\
\hline 28 & 16.1 & 16.1 & 15.2 & 16.2 & 17.9 & 16.1 \\
\hline 29 & 110.1 & 110.1 & 109.5 & 110.1 & 109.3 & 110.1 \\
\hline 30 & 25.0 & 25.3 & 19.7 & 25.0 & 19.2 & 25.0 \\
\hline
\end{tabular}

\subsubsection{Compound 2}

The HE fractions eluted with 7:3 hexane-chloroform provided a white solid (named triterpene 2). The IR spectrum shows an absorption at $3471 \mathrm{~cm}^{-1}$, which is attributed to a hydroxyl group. The absorptions at 1384 and $1172 \mathrm{~cm}^{-1}$ can be attributed to the asymmetric and symmetric $\mathrm{C}-\mathrm{O}$ stretches, respectively. The ${ }^{1} \mathrm{H}-\mathrm{NMR}$ and ${ }^{13} \mathrm{C}-\mathrm{NMR}$ spectra shows a large signal at $\delta_{\mathrm{H}} 3.74$ and a signal at $\delta_{\mathrm{C}}$ 
72.8 which are characteristic of a carbinolic carbon. The NMR data are similar to the corresponding ones described in the literature for the triterpene $\beta$-friedelinol [32].

\subsubsection{Compound 8}

The HE fractions eluted with 3:2 hexane-chloroform provided a white solid with molecular formula $\mathrm{C}_{30} \mathrm{H}_{50} \mathrm{O}_{2}$ as deduced from HR-APCIMS ( $\mathrm{m} / \mathrm{z} 443.3936[\mathrm{M}+\mathrm{H}]^{+}$, calc. 443.3922), named triterpene 8. The IR spectrum of 8 shows absorptions at 1726, 1288, and $1024 \mathrm{~cm}^{-1}$ (attributed to the $\mathrm{C}=\mathrm{O}$ and asymmetric and symmetric $\mathrm{C}-\mathrm{O}$ stretches, respectively) which are characteristic of a lactone group. The ${ }^{1} \mathrm{H}-\mathrm{NMR}$ spectrum of $\mathbf{8}$ shows a double-doublet signal at $\delta_{\mathrm{H}} 4.25(J=11.2$ and $5.2 \mathrm{~Hz}$, integrating for one hydrogen atom) which is characteristic of a hydrogen bonded to an oxygenated $\mathrm{sp}^{3}$ carbon and neighboring a methylene carbon in a cyclic system. The multiplet signal at $\delta_{\mathrm{H}} 2.65-2.49$ (integrating for two hydrogen atoms) can be attributed to the diastereotopic hydrogen atoms of a methylene group that is bonded to a carbonyl group and methylene group in a cyclic system. The seven singlet signals at $\delta_{\mathrm{H}} 1.18,1.09,1.04,0.99,0.97,0.95$, and 0.79 can be attributed to methyl groups bonded to non-hydrogenated carbon atoms. The triplet signal at $\delta_{\mathrm{H}} 0.78(\mathrm{~J}=7.4 \mathrm{~Hz})$ can be attributed to a methyl group bonded to a methylene carbon. The ${ }^{13} \mathrm{C}$-NMR spectrum of $\mathbf{8}$ shows a non-hydrogenated carbon signal at $\delta_{\mathrm{C}} 175.6$ which is attributed to the carbonyl carbon of a lactone group. The signal at $\delta_{\mathrm{C}} 84.1$ can be attributed to a methynic $\mathrm{sp}^{3}$ carbon bonded to the oxygen of the lactone group. The ${ }^{13} \mathrm{C}-\mathrm{NMR}$ spectrum also shows six non-hydrogenated $\left(\delta_{\mathrm{C}} 42.9,40.7,37.9,36.8,30.0\right.$, and 28.1$)$, three methynic $\left(\delta_{\mathrm{C}} 58.2,52.6\right.$, and 42.6$), 11$ methylenic $\left(\delta_{\mathrm{C}} 39.2,38.8,37.6,36.1,35.9,35.3,34.5,32.7,32.1,19.1\right.$, and 18.0), and eight methylic $\left(\delta_{\mathrm{C}} 34.9,31.7,32.0,22.1,19.9,19.3,13.6\right.$, and 7.7$)$ carbon atoms. The COSY contour map of 8 shows correlations of the signal at $\delta_{\mathrm{H}} 2.62(\mathrm{H}-2 \beta)$ with the signal at $\delta_{\mathrm{H}} 1.73$ $(\mathrm{H}-1 \alpha)$; the signal at $\delta_{\mathrm{H}} 4.25(\mathrm{H}-11)$ with the signals at $\delta_{\mathrm{H}} 1.67(\mathrm{H}-12 \beta)$ and $1.61(\mathrm{H}-12 \alpha)$; the signal at $\delta_{\mathrm{H}}$ $1.48(\mathrm{H}-21 \alpha)$ with the signal at $\delta_{\mathrm{H}} 0.97(\mathrm{H}-22 \beta)$; and the signal at $\delta_{\mathrm{H}} 0.78(\mathrm{H}-23)$ with the signals at $\delta_{\mathrm{H}}$ $1.32(\mathrm{H}-4 \beta)$ and $1.18(\mathrm{H}-4 \alpha)$. The HMBC contour map shows correlations of the hydrogen signals at $\delta_{\mathrm{H}}$ $1.73(\mathrm{H}-1 \alpha)$ and $1.58(\mathrm{H}-1 \beta)$ with the carbon signals at $\delta_{\mathrm{C}} 175.6(\mathrm{C}-3), 58.2(\mathrm{C}-10)$, and $34.5(\mathrm{C}-2)$. The hydrogen signals at $\delta_{\mathrm{H}} 2.62(\mathrm{H}-2 \beta)$ and $2.52(\mathrm{H}-2 \alpha)$ correlate with the carbon signals at $\delta_{\mathrm{C}} 175.6$ (C-3), $58.2(\mathrm{C}-10)$, and $19.1(\mathrm{C}-1)$. The hydrogen signal at $\delta_{\mathrm{H}} 4.25(\mathrm{H}-11)$ correlates with the carbon signals at $\delta_{\mathrm{C}} 58.2(\mathrm{C}-10), 37.6(\mathrm{C}-12)$, and $13.6(\mathrm{C}-25)$. The hydrogen signals at $\delta_{\mathrm{H}} 1.67(\mathrm{H}-12 \beta)$ and $1.61(\mathrm{H}-12 \alpha)$ correlate with the carbon signal at $\delta_{\mathrm{C}} 84.1(\mathrm{C}-11)$. The hydrogen signal at $\delta_{\mathrm{H}} 0.78(\mathrm{H}-23)$ correlates with the carbon signals at $\delta_{\mathrm{C}} 36.8(\mathrm{C}-5)$ and 36.1 (C-4). The hydrogen signal at $\delta_{\mathrm{H}} 0.79(\mathrm{H}-24)$ correlates with the carbon signals at $\delta_{\mathrm{C}} 58.2$ (C-10), 38.8 (C-6), 36.8 (C-5), and 36.1 (C-4). The hydrogen signal at $\delta_{\mathrm{H}} 0.97(\mathrm{H}-25)$ correlates with the carbon signals at $\delta_{\mathrm{C}} 84.1(\mathrm{C}-11), 58.2(\mathrm{C}-10)$, 52.6 (C-8), and 42.9 (C-9). The NMR data of 8 are in agreement with the data of the triterpene 3,4 -seco-friedelan-3,11 $\beta$-olide. In fact, the ${ }^{13} \mathrm{C}$-NMR data of $\mathbf{8}$ were compared with the seco-friedelanetype skeleton data compiled in the literature for 11 [33], which only presented significant differences in the functionalities at $\mathrm{C}-3$ and $\mathrm{C}-11$. The NMR data of C-14 to C-23 and C-26 to C-30 of 8 are very similar to the corresponding data of $\mathbf{1 1}$ (Table 2). BLYP/6-31G* geometry optimization calculations were carried out for $\mathbf{8}$ with a starting geometry based on the stereochemistry proposed for 3,4-secofriedelan-3,11-olide (see Figure 2). Two stereochemistry possibilities were considered for carbon C-11: H-11 $\alpha$ or H-11 $\beta$. 
Table 2. NMR data of $\mathbf{8}$ and corresponding data described in the literature for 11 [33].

\begin{tabular}{|c|c|c|c|c|c|c|}
\hline \multicolumn{6}{|c|}{ Triterpene 8} & \multirow{2}{*}{$\begin{array}{c}\text { Compound } 11 \\
\delta_{\mathrm{C}} \\
\end{array}$} \\
\hline Atom & Type & $\boldsymbol{\delta}_{\mathrm{C}}$ & $\delta_{H}$ & HMBC & COSY & \\
\hline 1 & $\mathrm{CH}_{2}$ & 19.1 & $\begin{array}{c}1.73(\mathrm{H} \alpha) \\
1.58(\mathrm{H} \beta)\end{array}$ & H- $2 \alpha ; \mathrm{H}-2 \beta$ & & 33.2 \\
\hline 2 & $\mathrm{CH}_{2}$ & 34.5 & $\begin{array}{c}2.52(\mathrm{H} \alpha) ; \\
J=13.2 ; \mathrm{t} \\
2.62(\mathrm{H} \beta) ; J=13.8 \\
\text { and } 6.6 \mathrm{~Hz} ; \mathrm{dd}\end{array}$ & $\mathrm{H}-1 \alpha ; \mathrm{H}-1 \beta$ & $\mathrm{H}-1 \alpha$ & 25.4 \\
\hline 3 & $\mathrm{C}$ & 175.6 & & H- $1 \alpha ; \mathrm{H}-1 \beta ; \mathrm{H}-2 \beta$ & & 76.3 \\
\hline 4 & $\mathrm{CH}_{2}$ & 36.1 & $\begin{array}{l}1.18(\mathrm{Ha}) ; \\
1.32(\mathrm{Hb})\end{array}$ & $\mathrm{H}-23 ; \mathrm{H}-24$ & & 37.2 \\
\hline 5 & $\mathrm{C}$ & 36.8 & & H-23; H-24 & & 50.1 \\
\hline 6 & $\mathrm{CH}_{2}$ & 38.8 & $\begin{array}{c}1.38(\mathrm{H} \alpha) \\
1.59(\mathrm{H} \beta)\end{array}$ & $\mathrm{H}-24$ & & 18.3 \\
\hline 7 & $\mathrm{CH}_{2}$ & 18.0 & $1.51(\mathrm{H} \alpha$ and $\mathrm{H} \beta)$ & & & 33.2 \\
\hline 8 & $\mathrm{CH}$ & 52.6 & $1.34(\mathrm{H} \alpha)$ & H-25; H-26 & & 41.9 \\
\hline 9 & $\mathrm{C}$ & 42.9 & & $\mathrm{H}-25$ & & 49.5 \\
\hline 10 & $\mathrm{CH}$ & 58.2 & $1.25(\mathrm{H} \alpha)$ & $\begin{array}{c}\text { H- } 1 \alpha ; \mathrm{H}-1 \beta ; \mathrm{H}-2 \alpha ; \mathrm{H}-2 \beta ; \\
\text { H- } 11 ; \mathrm{H}-24 ; \mathrm{H}-25\end{array}$ & & 37.5 \\
\hline 11 & $\mathrm{CH}$ & 84.1 & $\begin{array}{c}4.25(\mathrm{H} \alpha) ; J=5.2 \text { and } \\
11.2 \mathrm{~Hz} ; \mathrm{dd}\end{array}$ & H- $12 \alpha ; \mathrm{H}-12 \beta ; \mathrm{H}-25$ & H-12 & 20.9 \\
\hline 12 & $\mathrm{CH}_{2}$ & 37.6 & $\begin{array}{l}1.61(\mathrm{H} \alpha) ; \\
1.67(\mathrm{H} \beta)\end{array}$ & H-11; H-27 & & 23.9 \\
\hline 13 & $\mathrm{C}$ & 40.7 & & H-26; H-27 & & 48.9 \\
\hline 14 & $\mathrm{C}$ & 37.9 & & H-26 & & 42.1 \\
\hline 15 & $\mathrm{CH}_{2}$ & 32.1 & $1.54(\mathrm{H} \alpha$ and $\mathrm{H} \beta)$ & H-26 & & 33.6 \\
\hline 16 & $\mathrm{CH}_{2}$ & 35.9 & $\begin{array}{l}1.39(\mathrm{H} \beta) ; \\
1.56(\mathrm{H} \alpha)\end{array}$ & H-28 & & 21.6 \\
\hline 17 & $\mathrm{C}$ & 30.0 & & & & 54.9 \\
\hline 18 & $\mathrm{CH}$ & 42.6 & $1.61(\mathrm{H} \beta)$ & H-27; H-28 & & 44.7 \\
\hline 19 & $\mathrm{CH}_{2}$ & 35.3 & $\begin{array}{l}1.39(\mathrm{H} \alpha) \\
1.24(\mathrm{H} \beta)\end{array}$ & H-29; H-30 & & 41.9 \\
\hline 20 & $\mathrm{C}$ & 28.1 & & H-29; H-30 & & 27.4 \\
\hline 21 & $\mathrm{CH}_{2}$ & 32.7 & $1.48(\mathrm{H} \alpha)$ & H-29; H-30 & $\mathrm{H}-22 \beta$ & 46.5 \\
\hline 22 & $\mathrm{CH}_{2}$ & 39.2 & $\begin{array}{l}1.49(\mathrm{H} \alpha) \\
0.97(\mathrm{H} \beta)\end{array}$ & H-28 & & 148.7 \\
\hline 23 & $\mathrm{CH}_{3}$ & 7.7 & $0.78 ; J=7.4 \mathrm{~Hz} ; \mathrm{t}$ & & $\mathrm{H}-4$ & 28.6 \\
\hline 24 & $\mathrm{CH}_{3}$ & 22.1 & $0.79 ; \mathrm{s}$ & & & 22.5 \\
\hline 25 & $\mathrm{CH}_{3}$ & 13.6 & $0.97 ; \mathrm{s}$ & $\mathrm{H}-11$ & & 15.7 \\
\hline 26 & $\mathrm{CH}_{3}$ & 19.9 & $1.04 ; \mathrm{s}$ & & & 16.6 \\
\hline 27 & $\mathrm{CH}_{3}$ & 19.3 & $1.09 ; \mathrm{s}$ & & & 16.8 \\
\hline 28 & $\mathrm{CH}_{3}$ & 32.0 & $1.18 ; \mathrm{s}$ & & & 16.1 \\
\hline 29 & $\mathrm{CH}_{3}$ & 34.9 & $0.95 ; \mathrm{s}$ & $\mathrm{H}-30$ & & 110.1 \\
\hline 30 & $\mathrm{CH}_{3}$ & 31.7 & $0.99 ; \mathrm{s}$ & $\mathrm{H}-29$ & & 25.3 \\
\hline
\end{tabular}


The optimized geometry of 3,4-seco-friedelan-3,11 $\beta$-olide shows lower energy than the optimized geometry of 3,4-seco-friedelan-3,11 $\alpha$-olide $\left(E^{\text {electr-nucl. }}=-1322.96006656\right.$ and -1322.94516689 a.u., respectively), corresponding to $\Delta E^{\text {electr-nucl. }}=9.34 \mathrm{kcal} / \mathrm{mol}$. The geometry of 3,4-seco-friedelan3,11 $\beta$-olide, which does not have the ring $\mathrm{A}$, presents rings $\mathrm{B}$ and $\mathrm{C}$ in the chair conformation and rings $\mathrm{D}$ and $\mathrm{E}$ in the boat conformation. Carbon chemical shift calculations were carried out for both the optimized geometries at the same level of theory (BLYP/6-31G*). Correlations between values of calculated carbon chemical shifts and experimental ${ }^{13} \mathrm{C}-\mathrm{NMR}$ data of $\mathbf{8}$ (Table 2) provided a higher correlation coefficient and slope $\left(R^{2}=0.98055\right.$ and $\left.\alpha=0.90931\right)$ for 3,4-seco-friedelan-3,11 $\beta$-olide than the corresponding values for 3,4-seco-friedelan-3,11 $\alpha$-olide $\left(R^{2}=0.97441\right.$ and $\left.\alpha=0.89006\right)$. These theoretical results are in agreement with the stereochemistry of 3,4-seco-friedelan-3,11 $\beta$-olide proposed for $\mathbf{8}$, a triterpene not yet described in the literature.

\subsubsection{Compound 9}

The HE fractions eluted with 3:2 hexane-chloroform also provided a white solid with molecular formula $\mathrm{C}_{30} \mathrm{H}_{50} \mathrm{O}$ as deduced from HR-APCIMS ( $\mathrm{m} / \mathrm{z} 409.3855[\mathrm{M}+\mathrm{H}-18]^{+}$, calc. 409.3834), named triterpene 9. The IR spectrum shows an absorption at $3488 \mathrm{~cm}^{-1}$ which is characteristic of a hydroxyl group. The weak absorption at $1640 \mathrm{~cm}^{-1}$ can be attributed to an alkenyl group. The absorptions at 1372 and $1050 \mathrm{~cm}^{-1}$ can be attributed to the asymmetric and symmetric $\mathrm{C}-\mathrm{O}$ stretches, respectively. The ${ }^{1} \mathrm{H}-\mathrm{NMR}$ spectrum shows a signal at $\delta_{\mathrm{H}} 4.79$ (integrating for two hydrogen atoms) which is characteristic of the alkenyl hydrogen atoms of a methylenic carbon. Then, the other alkenyl carbon is non-hydrogenated. The multiplet at $\delta_{\mathrm{H}} 3.25-3.21$ can be attributed to a carbinolic hydrogen. The multiplet at $\delta_{\mathrm{H}} 2.71-2.64$ corresponds to a hydrogen neighboring an alkenyl group. The singlets at $\delta_{\mathrm{H}}$ $1.75,1.02,0.97,0.94,0.83,0.81$, and 0.73 can be attributed to methylic hydrogen atoms. The ${ }^{13} \mathrm{C}-\mathrm{NMR}$ spectrum shows signals at $\delta_{\mathrm{C}} 148.6$ (non-hydrogenated carbon) and 110.2 (methylenic carbon) which are characteristic of an alkenyl group. The signal at $\delta_{\mathrm{C}} 78.4$ is characteristic of a carbinolic carbon. The

${ }^{13} \mathrm{C}$-NMR spectrum also shows other signals which are attributed to five non-hydrogenated $\left(\delta_{\mathrm{C}} 44.8\right.$, $42.1,41.7,39.0$, and 37.2$)$, five methynic $\left(\delta_{\mathrm{C}} 55.3,54.9,50.4,49.5\right.$, and 46.5$), 10$ methylenic $\left(\delta_{\mathrm{C}} 41.9\right.$, $38.9,33.7,33.4,27.5,27.4,24.0,21.7,21.1$, and 18.5$)$, and seven methylic $\left(\delta_{\mathrm{C}} 28.2,25.0,16.7,16.6\right.$, 16.1, 15.9, and 15.7) carbon atoms (see Table 3). The COSY contour map of 9 shows correlations of the signal at $\delta_{\mathrm{H}} 3.23(\mathrm{H}-3)$ with the signal at $\delta_{\mathrm{H}} 1.65(\mathrm{H}-2)$; the signals at $\delta_{\mathrm{H}} 1.53(\mathrm{H}-6 \beta)$ and $1.40(\mathrm{H}-6 \alpha)$ with the signal at $\delta_{\mathrm{H}} 0.71(\mathrm{H}-5)$; the signals at $\delta_{\mathrm{H}} 1.97(\mathrm{H}-20 \beta)$ and $1.86(\mathrm{H}-20 \alpha)$ with the signals at $\delta_{\mathrm{H}}$ $1.61(\mathrm{H}-19 \alpha)$ and $1.04(\mathrm{H}-19 \beta)$; the signal at $\delta_{\mathrm{H}} 2.67(\mathrm{H}-21)$ with the signals at $\delta_{\mathrm{H}} 1.39(\mathrm{H}-17), 1.97$ $(\mathrm{H}-20 \beta)$, and $1.86(\mathrm{H}-20 \alpha)$; the signal at $\delta_{\mathrm{H}} 4.79(\mathrm{H}-29)$ with the signals at $\delta_{\mathrm{H}} 2.67(\mathrm{H}-21)$ and 1.75 (H-30). The HMBC contour map shows correlations of the hydrogen signal at $\delta_{\mathrm{H}} 3.23(\mathrm{H}-3)$ with the carbon signals at $\delta_{\mathrm{C}} 39.0(\mathrm{C}-4), 28.2(\mathrm{C}-23)$, and $15.7(\mathrm{C}-24)$; the hydrogen signal at $\delta_{\mathrm{H}} 2.67(\mathrm{H}-21)$ with the carbon signals at $148.6(\mathrm{C}-22), 110.2(\mathrm{C}-29), \delta_{\mathrm{C}} 54.9(\mathrm{C}-17), 44.8(\mathrm{C}-18), 27.4(\mathrm{C}-20)$, and $25.0(\mathrm{C}-30)$; the hydrogen signal at $\delta_{\mathrm{H}} 4.79(\mathrm{H}-29)$ with the carbon signals at $148.6(\mathrm{C}-22), \delta_{\mathrm{C}} 46.5(\mathrm{C}-21)$, and $25.0(\mathrm{C}-30)$; the hydrogen signal at $\delta_{\mathrm{H}} 1.75(\mathrm{H}-30)$ with the carbon signals at $148.6(\mathrm{C}-22), 110.2$ $(\mathrm{C}-29)$, and $\delta_{\mathrm{C}} 46.5(\mathrm{C}-21)$. 
Table 3. NMR data of triterpene 9 and corresponding data described in the literature for 12 [26].

\begin{tabular}{|c|c|c|c|c|c|c|}
\hline \multicolumn{6}{|c|}{ Triterpene 9} & \multirow{2}{*}{$\frac{\text { Compound } 12}{\delta_{\mathrm{C}}}$} \\
\hline Atom & Type & $\delta_{\mathrm{C}}$ & $\delta_{\mathrm{H}}$ & HMBC & COSY & \\
\hline 1 & $\mathrm{CH}_{2}$ & 38.9 & $\begin{array}{c}0.94(\mathrm{H} \alpha) \\
1.70(\mathrm{H} \beta)\end{array}$ & $\mathrm{H}-25$ & & 33.2 \\
\hline 2 & $\mathrm{CH}_{2}$ & 27.5 & $1.63(\mathrm{H} \alpha$ and $\mathrm{H} \beta)$ & & & 25.4 \\
\hline 3 & $\mathrm{CH}$ & 78.4 & $3.23(\mathrm{H} \alpha) ; \mathrm{m}$ & $\mathrm{H}-23 ; \mathrm{H}-24$ & $\mathrm{H}-2$ & 76.3 \\
\hline 4 & $\mathrm{C}$ & 39.0 & & H-3; H-23; H-24 & & 37.2 \\
\hline 5 & $\mathrm{CH}$ & 55.3 & $0.69(\mathrm{H} \alpha)$ & H-23; H-24; H-25 & & 50.1 \\
\hline 6 & $\mathrm{CH}_{2}$ & 18.5 & $\begin{array}{c}1.40(\mathrm{H} \alpha) ; \\
1.53(\mathrm{H} \beta)\end{array}$ & & H-5 & 18.3 \\
\hline 7 & $\mathrm{CH}_{2}$ & 33.4 & $\begin{array}{c}1.47(\mathrm{H} \alpha) \\
1.62(\mathrm{H} \beta)\end{array}$ & H-26 & & 33.2 \\
\hline 8 & $\mathrm{C}$ & 41.7 & & H-26; H-27 & & 41.9 \\
\hline 9 & $\mathrm{CH}$ & 50.4 & $1.24(\mathrm{H} \alpha)$ & H-25; H-26 & & 49.5 \\
\hline 10 & $\mathrm{C}$ & 37.2 & & H-5; H-25 & & 37.5 \\
\hline 11 & $\mathrm{CH}_{2}$ & 21.1 & $\begin{array}{l}1.51(\mathrm{H} \alpha) \\
1.32(\mathrm{H} \beta)\end{array}$ & & & 20.9 \\
\hline 12 & $\mathrm{CH}_{2}$ & 24.0 & $\begin{array}{l}1.43(\mathrm{H} \alpha) ; \\
1.49(\mathrm{H} \beta)\end{array}$ & & & 23.9 \\
\hline 13 & $\mathrm{CH}$ & 49.5 & $1.37(\mathrm{H} \beta)$ & H-27; H-28 & & 48.9 \\
\hline 14 & $\mathrm{C}$ & 42.1 & & H-26; H-27 & & 42.1 \\
\hline 15 & $\mathrm{CH}_{2}$ & 33.7 & $\begin{array}{c}1.42(\mathrm{H} \alpha) \\
1.24(\mathrm{H} \beta)\end{array}$ & $\mathrm{H}-27$ & & 33.6 \\
\hline 16 & $\mathrm{CH}_{2}$ & 21.7 & $\begin{array}{c}1.74(\mathrm{H} \alpha) ; \\
1.65(\mathrm{H} \beta)\end{array}$ & & & 21.6 \\
\hline 17 & $\mathrm{CH}$ & 54.9 & $1.39(\mathrm{H} \beta)$ & $\mathrm{H}-21 ; \mathrm{H}-28$ & & 54.9 \\
\hline 18 & $\mathrm{C}$ & 44.8 & & H-21; H-28 & & 44.7 \\
\hline 19 & $\mathrm{CH}_{2}$ & 41.9 & $\begin{array}{c}1.60(\mathrm{H} \alpha) \\
1.04(\mathrm{H} \beta)\end{array}$ & H-28 & & 41.9 \\
\hline 20 & $\mathrm{CH}_{2}$ & 27.4 & $\begin{array}{c}1.84(\mathrm{H} \alpha) \\
1.97(\mathrm{H} \beta)\end{array}$ & $\mathrm{H}-21$ & H-19 & 27.4 \\
\hline 21 & $\mathrm{CH}$ & 46.5 & $\begin{array}{c}2.67(\mathrm{H} \beta) ; \\
J=16.6 \text { and } \\
9.0 \mathrm{~Hz} ; \mathrm{dd}\end{array}$ & H-29; H-30 & $\begin{array}{l}\text { H-17; } \\
\text { H-20 }\end{array}$ & 46.5 \\
\hline 22 & $\mathrm{C}$ & 148.6 & & H-21; H-29; H-30 & & 148.7 \\
\hline 23 & $\mathrm{CH}_{3}$ & 28.2 & $1.02 ; \mathrm{s}$ & H-3; H-24 & & 28.6 \\
\hline 24 & $\mathrm{CH}_{3}$ & 15.7 & $0.81 ; \mathrm{s}$ & H-3; H-23 & & 22.5 \\
\hline 25 & $\mathrm{CH}_{3}$ & 16.7 & $0.83 ; \mathrm{s}$ & & & 15.7 \\
\hline 26 & $\mathrm{CH}_{3}$ & 15.9 & $0.94 ; \mathrm{s}$ & & & 16.6 \\
\hline 27 & $\mathrm{CH}_{3}$ & 16.7 & $0.97 ; \mathrm{s}$ & & & 16.8 \\
\hline 28 & $\mathrm{CH}_{3}$ & 16.1 & $0.73 ; \mathrm{s}$ & & & 16.1 \\
\hline 29 & $\mathrm{CH}_{2}$ & 110.2 & $4.79 ; \mathrm{s}$ & $\mathrm{H}-21 ; \mathrm{H}-30$ & $\begin{array}{l}\mathrm{H}-30 \\
\mathrm{H}-21\end{array}$ & 110.1 \\
\hline 30 & $\mathrm{CH}_{3}$ & 25.0 & $1.75 ; \mathrm{s}$ & $\mathrm{H}-21 ; \mathrm{H}-29$ & & 25.3 \\
\hline
\end{tabular}


The NMR analyses of 9 are in agreement with the data of the triterpene $3 \beta$-hydroxy- $21 \beta$ - $H$-hop22(29)-ene. In fact, the ${ }^{13} \mathrm{C}$-NMR data of 9 were compared with the hopane-type skeleton data compiled in the literature for 12 [26], and seen to only present a significant difference in the stereochemistry at C-3. The NMR data of C-6 to C-8, C-10 to C12, C-14 to C-23, and C-27 to C-30 of 9 are very similar to the corresponding data of 12 (Table 3). BLYP/6-31G* geometry optimization calculations were carried out for 9 with a starting geometry based on the stereochemistry proposed to $3 \beta$-hydroxy- $21 \beta$ - $H$ hop-22(29)-ene (Figure 2). The most stable optimized geometry ( $E=-1247.70633974$ a.u.) presents the rings $\mathrm{A}, \mathrm{B}, \mathrm{C}$, and $\mathrm{D}$ in the chair conformation and the ring $\mathrm{E}$ in the envelope one. Moreover, the $\mathrm{C}-29$ of the allyl group is positioned close to the methyl group at C-28. Carbon chemical shift calculations were carried out to the optimized geometry of 9 at the same level of theory (BLYP/6-31G*). Correlations between values of calculated carbon chemical shifts and experimental ${ }^{13} \mathrm{C}$-NMR data of 9 (Table 3) provided a high correlation coefficient $\left(R^{2}=0.98817\right)$ and slope of the $R^{2}$ curve $(\alpha=0.93702)$. These theoretical results are in agreement with the stereochemistry of $3 \beta$-hydroxy-21 $\beta$-H-hop-22(29)-ene for 9 , a triterpene not yet described in the literature.

\subsubsection{Compounds $\mathbf{1 0}$ and $\mathbf{1 1}$}

The HE fractions eluted with 1:1 hexane-chloroform provided a white solid. The IR spectrum of the solid shows a large absorption at 3250-2700 $\mathrm{cm}^{-1}$ and an intense absorption at $1701 \mathrm{~cm}^{-1}$ which are characteristic of a carboxylic acid group. Moreover, the absorptions at 1284 and $1049 \mathrm{~cm}^{-1} \mathrm{can}_{\text {be }}$ attributed to the asymmetric and symmetric $\mathrm{C}-\mathrm{O}$ stretches, respectively. The ${ }^{1} \mathrm{H}-\mathrm{NMR}$ spectrum shows a broad signal at $\delta_{\mathrm{H}} 4.78$ (integrating for two hydrogen atoms) which is characteristic of an alkenyl group. The ${ }^{13} \mathrm{C}-\mathrm{NMR}$ spectrum shows two groups of 30 signals, each with significant differences in intensity. The ${ }^{13} \mathrm{C}-\mathrm{NMR}$ data of the group of low-intensity signals (named triterpene 10) present a signal at $\delta_{\mathrm{C}} 180.1$ which is characteristic of a carboxylic carbon. The signals at $\delta_{\mathrm{C}} 148.7$ and 110.1 (non-hydrogenated and methylenic carbon atoms, respectively) are characteristic of an alkenyl group. The ${ }^{13} \mathrm{C}-\mathrm{NMR}$ data of $\mathbf{1 0}$ were compared with the corresponding data compiled in the literature for $\mathbf{1 4}$ and 15 (see Table 1). Triterpene 10 only differs in the position of the allyl group and the opening of the ring $\mathrm{A}$ in relation to $\mathbf{1 4}$ and 15, respectively (see Figure 2). The NMR data of C-1 to C-5, C-8, C-9, and $\mathrm{C}-11$ of $\mathbf{1 4}$ are very similar to the corresponding data of $\mathbf{1 0}$. On the other hand, the NMR data of the C-12 to $\mathrm{C}-22$ of $\mathbf{1 0}$ are very similar to the corresponding data of $\mathbf{1 5}$. As result, it can be proposed that the chemical structure of $\mathbf{1 0}$ is in agreement with the structure of the triterpene 3,4-seco-21 $\beta$ - $H$-hop22(29)-en-3-oic acid, a triterpene which was not yet described in the literature. BLYP/6-31G* geometry optimization calculations were carried out for $\mathbf{1 0}$ with starting geometry based on the stereochemistry proposed for 3,4-seco-21 $\beta$ - $H$-hop-22(29)-en-3-oic acid (see Figure 2). The most stable optimized geometry ( $E=-1322.93835876$ a.u.), which does not have the ring A, presents the rings $\mathrm{B}$, $\mathrm{C}$, and $\mathrm{D}$ in the chair conformation and ring $\mathrm{E}$ in the envelope one. Carbon chemical shift calculations were carried out to the optimized geometry of $\mathbf{1 0}$ at the same level of theory (BLYP/6-31G*). Correlations between values of calculated carbon chemical shifts and experimental ${ }^{13} \mathrm{C}-\mathrm{NMR}$ data of 10 (Table 1) provided high correlation coefficient $\left(R^{2}=0.97833\right)$ and slope of the $R^{2}$ curve $(\alpha=0.87424)$. These theoretical results are in agreement with the stereochemistry of 3,4-seco-21 $\beta$ - $H$ hop-22(29)-en-3-oic acid proposed for 10, a triterpene not yet described in the literature. In turn, the 
${ }^{13} \mathrm{C}-\mathrm{NMR}$ data of the group of high intensity signals (named triterpene 11) also presents a signal characteristic of carboxyl carbon (at $\delta_{\mathrm{C}} 178.2$ ). The ${ }^{13} \mathrm{C}-\mathrm{NMR}$ data of $\mathbf{1 1}$ are similar to the corresponding data described in the literature for 3,4-seco-friedelan-3-oic acid [33]. Moreover, the intensity and integration of the carbonyl carbon atom signals based on quantitative ${ }^{13} \mathrm{C}-\mathrm{NMR}$ analysis indicates a mixture 2:3 of compounds $\mathbf{1 0}$ and $\mathbf{1 1}$, respectively.

\subsection{In Vitro AChE Inhibitory Activity}

The AChE activity was measured for the triterpenes 4, 9, and mixture of $\mathbf{1 1}$ and sitosterol which were previously obtained from the leaves of M. robusta. The calorimetric method of Ellman was adapted for 96 -well microplates in the assays at $25{ }^{\circ} \mathrm{C}$ [30]. The triterpenes 4 and 9 showed (64 \pm 3$) \%$ and $(76 \pm 1) \%$ of inhibition, respectively. The mixture of triterpene $\mathbf{1 1}$ and sitosterol exhibited very significant results, i.e., $(94 \pm 1) \%$ of inhibition.

\section{Experimental}

\subsection{General Procedures}

Uncorrected melting points were determined using a Microquímica apparatus, model MQAPF-302. Optical rotations were measured on a Perkin-Elmer Model 341 polarimeter using a $100 \mathrm{~mm}, 1.0 \mathrm{~mL}$ capacity cell. The IR spectra were taken on a Perkin Elmer-Spectrum One (ATR) spectrometer. The ${ }^{1} \mathrm{H}$ and ${ }^{13} \mathrm{C}$-NMR spectra at 400.129 and $100.613 \mathrm{MHz}$, respectively, as well as the COSY, HSQC, and $\mathrm{HMBC}$ experiments were performed on a Brüker DRX400 AVANCE spectrometer, using $\mathrm{CDCl}_{3}$ or a mixture of $\mathrm{CDCl}_{3} /$ pyridine- $\mathrm{d}_{5}$ as solvent, with direct or inverse probes and a field gradient. The chemical shifts were registered in ppm $(\delta)$ relative to TMS as the internal standard. The coupling constants $(J)$ were registered in Hertz. HR-APCIMS spectra were acquired on a Shimadzu LCMS-IT-TOF system. Analyses were carried out using manual injection. The samples were dissolved in $\mathrm{CHCl}_{3}$ and then diluted with $\mathrm{MeOH}$. Column chromatography (CC) processes were carried out using silica gel 60 (70-230 Mesh). Thin layer chromatography (TLC) processes were carried out using precoated silica gel plates.

\subsection{Phytochemical Methodology}

\subsubsection{Plant Material}

Leaves of M. robusta were collected in June 2010 at the Parque Estadual do Itacolomi, in the City of Ouro Preto, State of Minas Gerais, Brazil. After botanical identification, the voucher specimen of M. robusta was deposited in the Herbário Professor José Badini, Universidade Federal de Ouro Preto, under the code OUPR: 25,559.

\subsubsection{Extraction and Isolation of Constituents}

Leaves of M. robusta were dried at room temperature until a constant weight was achieved (about one week) and finally powdered. A sample of this material $(864.4 \mathrm{~g})$ was submitted to extraction with hexane (3 L, 5 days, room temperature). A solid material (SM; $4.51 \mathrm{~g}$ ) precipitated during solvent 
evaporation, being separated by filtration under reduced pressure. The SM was submitted to column chromatography using silica gel as the stationary phase (CCS) eluted with hexane, chloroform, ethyl acetate, and methanol in increasing polarity order. The triterpenes 1-6 (Figure 1) were obtained, as previously reported [18].

The rest of the hexane extract provided a viscous crude oil (HE; $32.0 \mathrm{~g})$ after complete solvent evaporation. A part of HE (31.43 g) was submitted to CCS eluted with hexane, chloroform, ethyl acetate, and methanol in increasing polarity order. The HE fractions eluted with hexane-chloroform (9:1) were again submitted to CCS eluted with hexane and chloroform in increasing polarity order. The fractions eluted with hexane-chloroform (1:1) provided a white solid (13.5 $\mathrm{mg}$ ) which was identified as a mixture of the triterpenes $\mathbf{1}$ and 7. The HE fractions eluted with hexane-chloroform (4:1) provided a white solid (624.0 $\mathrm{mg}$ ) which was identified as triterpene 1. The HE fractions eluted with hexane-chloroform (7:3) provided a solid $(566.1 \mathrm{mg})$ which was identified as triterpene 2.

The HE fractions eluted with hexane-chloroform (3:2) were again submitted to CCS eluted with hexane, chloroform, ethyl acetate, and methanol in increasing polarity order. The fractions hexane-chloroform (3:7) provided a white solid $(14.1 \mathrm{mg})$ which was identified as triterpene 8 . The fractions eluted with chloroform $(289.0 \mathrm{mg})$ were submitted to CCS eluted with chloroform, providing a white solid (103.0 mg) which was identified as triterpene 9.

The HE fractions eluted with hexane-chloroform (1:1) were again submitted to CCS eluted with hexane, chloroform, ethyl acetate, and methanol in increasing polarity order. The fractions eluted with hexane-chloroform $(3: 7)$ provided a white solid $(59.5 \mathrm{mg})$ which was identified as a mixture of the triterpenes $\mathbf{1 0}$ and 11. The fractions eluted with hexane-chloroform (1:9) provided a white solid (83.8 $\mathrm{mg})$ which was identified as a mixture of $\mathbf{1 1}$ and the steroid sitosterol.

Friedelin (1): white solid (624.0 mg); m.p. 251-254 ${ }^{\circ}$ C; IR (ATR; $\mathrm{cm}^{-1}$ ) v 2972, 2926, 2868, 1711, 1461, 1389, 1299, 1189, 1073, 1002, 982, and 924; ${ }^{1} \mathrm{H}-\mathrm{NMR}\left(400 \mathrm{MHz} ; \mathrm{CDCl}_{3} ; \mathrm{ppm}\right) \delta_{\mathrm{H}} 2.42-2.40$ (multiplet; 1H), 2.38-2.37 (multiplet; 2H), 1.97-1.94 (multiplet; 1H), 1.77-1.34 (superposed signals; $21 \mathrm{H}), 1.29(\mathrm{~s} ; 3 \mathrm{H}), 1.18(\mathrm{~s} ; 3 \mathrm{H}), 1.05(\mathrm{~s} ; 3 \mathrm{H}), 1.01(\mathrm{~s} ; 3 \mathrm{H}), 0.95(\mathrm{~s} ; 3 \mathrm{H}), 0.89(\mathrm{~d}, J=6.4 \mathrm{~Hz} ; 3 \mathrm{H}), 0.87$ $(\mathrm{s} ; 3 \mathrm{H})$, and $0.73(\mathrm{~s} ; 3 \mathrm{H}) ;{ }^{13} \mathrm{C}-\mathrm{NMR}\left(100 \mathrm{MHz} ; \mathrm{CDCl}_{3} ; \mathrm{ppm}\right) \delta_{\mathrm{C}} 213.2(\mathrm{C}-3), 59.5(\mathrm{C}-10), 58.2(\mathrm{C}-4)$, 53.1 (C-8), 42.8 (C-18), 42.2 (C-5), 41.5 (C-2), 41.3 (C-6), 39.7 (C-14), 39.3 (C-22), 38.3 (C-13), 37.5 (C-9), 36.0 (C-16), 35.6 (C-11), 35.4 (C-19), 35.0 (C-29), 32.8 (C-21), 32.4 (C-15), 32.1 (C-28), 31.8 (C-30), 30.5 (C-12), 30.0 (C-17), 28.2 (C-20), 22.3 (C-1), 20.3 (C-26), 18.7 (C-27), 18.3 (C-7), 18.0 (C-25), 14.7 (C-24), and 6.8 (C-23). HR-APCIMS ( $m / z$ 427.3969 [M+H] $]^{+}$, calc. 427.3934).

B-Friedelinol (2): white solid (566.1 mg); m.p. 271-276 ${ }^{\circ} \mathrm{C}$; IR (ATR; $\mathrm{cm}^{-1}$ ) $v$ 3619, 3471, 2915, $2869,1448,1384,1360,1172,1089,1020,1000,979$, and $920 ;{ }^{1} \mathrm{H}-\mathrm{NMR}\left(200 \mathrm{MHz} ; \mathrm{CDCl}_{3} ; \mathrm{ppm}\right) \delta_{\mathrm{H}}$ $3.74(1 \mathrm{~s} ; \mathrm{H}-3 ; 1 \mathrm{H})$ and $2.50-0.80$ (superposed signals); ${ }^{13} \mathrm{C}-\mathrm{NMR}\left(50 \mathrm{MHz} ; \mathrm{CDCl}_{3} ; \mathrm{ppm}\right) \delta_{\mathrm{C}} 72.8$ (C-3), 61.3 (C-10), 53.2 (C-8), 49.1 (C-4), 42.8 (C-18), 41.7 (C-6), 39.7 (C-14), 39.3 (C-22), 38.4 (C-13), 37.8 (C-5), 37.1 (C-9), 36.1 (C-2), 35.5 (C-16), 35.3 (C-11), 35.2 (C-19), 35.0 (C-29), 32.8 (C-21), 32.3 (C-15), 32.1 (C-28), 31.8 (C-30), 30.6 (C-12), 30.0 (C-17), 28.2 (C-20), 20.1 (C-26), 18.6 (C-27), 18.2 (C-25), 17.5 (C-7), 16.4 (C-24), 15.8 (C-1), and 11.6 (C-23); HR-APCIMS $\left(\mathrm{m} / \mathrm{z} 411.3966[\mathrm{M}+\mathrm{H}-18]^{+}\right.$, calc. 411.3985$)$. 
3-Oxo-21 $\beta$-H-hop-22(29)-ene (7): white solid (13.5 mg) obtained in mixture with 1; ${ }^{1} \mathrm{H}-\mathrm{NMR}$ (200 MHz; $\left.\mathrm{CDCl}_{3} ; \mathrm{ppm}\right) \delta_{\mathrm{H}} 4.78(1 \mathrm{~s} ; 2 \mathrm{H})$ and $2.43-0.73$ (superposed signals). The ${ }^{13} \mathrm{C}-\mathrm{NMR}$ data of 7 are shown in Table 1.

3,4-seco-Friedelan-3,11 $\beta$-olide (8): white solid (14.1 mg); m.p. $184-187{ }^{\circ} \mathrm{C}$; IR (ATR; $\mathrm{cm}^{-1}$ ) 2962, 2850, 1726, 1458, 1386, 1288, and 1024; ${ }^{1} \mathrm{H}\left(400 \mathrm{MHz} ; \mathrm{CDCl}_{3} ; \mathrm{ppm}\right) \delta_{\mathrm{H}} 4.25$ (dd, $J=11.2$ and $5.2 \mathrm{~Hz}$; $\mathrm{H}-11 \alpha), 2.62(\mathrm{dd}, J=13.8$ and $6.6 \mathrm{~Hz} ; \mathrm{H}-2 \beta), 2.52(\mathrm{t}, J=13.2 \mathrm{~Hz} ; \mathrm{H}-2 \alpha), 1.73(\mathrm{H}-1 \alpha), 1.67(\mathrm{H}-12 \beta)$, $1.61(\mathrm{H}-12 \alpha$ and $\mathrm{H}-18 \beta), 1.59(\mathrm{H}-6 \beta), 1.58(\mathrm{H}-1 \beta), 1.56(\mathrm{H}-16 \alpha), 1.54(\mathrm{H}-15 \alpha$ and $\mathrm{H}-15 \beta), 1.51(\mathrm{H}-7 \alpha$ and $\mathrm{H}-7 \beta), 1.49(\mathrm{H}-22 \alpha), 1.48(\mathrm{H}-21 \alpha), 1.39(\mathrm{H}-16 \beta, \mathrm{H}-17 \beta$, and $\mathrm{H}-19 \alpha), 1.38(\mathrm{H}-6 \alpha), 1.34(\mathrm{H}-8 \alpha)$, $1.32(\mathrm{H}-4 \mathrm{~b}), 1.30(\mathrm{H}-21 \beta), 1.25(\mathrm{H}-10 \alpha), 1.24(\mathrm{H}-19 \beta), 1.18(\mathrm{H}-4 \mathrm{a}$ and $\mathrm{H}-28), 1.09(\mathrm{H}-27), 1.04$ (H-26), 0.99 (H-30), 0.97 (H-22 $\beta$ and H-25), 0.95 (H-29), 0.79 (H-24), and 0.78 (t, $J=7.4 \mathrm{~Hz}$; H-23); the ${ }^{13} \mathrm{C}-\mathrm{NMR}$ data of 8 are shown in Table 2; HR-APCIMS $\left(\mathrm{m} / \mathrm{z} 443.3936[\mathrm{M}+\mathrm{H}]^{+}\right.$, calc. 443.3922$)$.

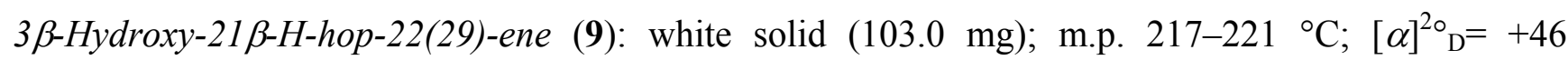
$\left(c=2.22 \times 10^{-3} \mathrm{M} ; \mathrm{CHCl}_{3}\right) ; \mathrm{IR}\left(\mathrm{ATR} ; \mathrm{cm}^{-1}\right) v 3488,2931,2870,1640,1445,1372,896$, and 886; ${ }^{1} \mathrm{H}-\mathrm{NMR}\left(400 \mathrm{MHz} ; \mathrm{CDCl}_{3} /\right.$ pyridine-d $\left._{5} ; \mathrm{ppm}\right) \delta_{\mathrm{H}} 4.79(\mathrm{~s} ; \mathrm{H}-29), 3.23(\mathrm{~m} ; \mathrm{H}-3 \alpha), 2.67$ (dd, $J=16.6$ and $9.0 \mathrm{~Hz} ; \mathrm{H}-21), 1.97(\mathrm{H}-20 \beta), 1.84(\mathrm{H}-20 \alpha), 1.75(\mathrm{H}-30), 1.74(\mathrm{H}-16 \alpha), 1.70(\mathrm{H}-1 \beta), 1.65(\mathrm{H}-16 \beta)$, $1.63(\mathrm{H}-2 \alpha$ and $\mathrm{H}-2 \beta), 1.62(\mathrm{H}-7 \beta), 1.60(\mathrm{H}-19 \alpha), 1.53(\mathrm{H}-6 \beta), 1.51(\mathrm{H}-11 \alpha), 1.49(\mathrm{H}-12 \beta), 1.47(\mathrm{H}-$ $7 \alpha), 1.43(\mathrm{H}-12 \alpha), 1.42(\mathrm{H}-15 \alpha), 1.40(\mathrm{H}-6 \alpha), 1.39(\mathrm{H}-17 \beta), 1.37$ (H-13 $\beta), 1.32(\mathrm{H}-11 \beta), 1.24(\mathrm{H}-9 \alpha$ and $\mathrm{H}-15 \beta), 1.04$ (H-19 $\beta), 1.02$ (H-23), 0.97 (H-27), 0.94 (H-1 $\alpha$ and H-26), $0.83(\mathrm{H}-25), 0.81(\mathrm{H}-24)$, $0.73(\mathrm{H}-28)$, and $0.69(\mathrm{H}-5 \alpha)$; the ${ }^{13} \mathrm{C}-\mathrm{NMR}$ data of 9 are shown in Table 3; HR-APCIMS $\left(\mathrm{m} / \mathrm{z} 409.3855[\mathrm{M}+\mathrm{H}-18]^{+}\right.$, calc. 409.3834).

3,4-seco-21 $\beta$-H-Hop-22(29)-en-3-oic acid (10): white solid obtained as a mixture with 11 (59.5 mg); ${ }^{1} \mathrm{H}-\mathrm{NMR}\left(400 \mathrm{MHz} ; \mathrm{CDCl}_{3} ; \mathrm{ppm}\right) \delta_{\mathrm{H}} 4.78(\mathrm{ls} ; 2 \mathrm{H}), 2.67(\mathrm{dd}, J=16.4$ and $9.6 \mathrm{~Hz}), 2.38(\mathrm{t}, J=8.7 \mathrm{~Hz})$, 1.75-0.73 (superposed signals). The ${ }^{13} \mathrm{C}-\mathrm{NMR}$ data of $\mathbf{1 0}$ are shown in Table 1.

3,4-seco-Friedelan-3-oic acid (11) [33]: white solid obtained in mixture with 10 (59.5 mg); ${ }^{1} \mathrm{H}-\mathrm{NMR}$ $\left(400 \mathrm{MHz} ; \mathrm{CDCl}_{3} ; \mathrm{ppm}\right) \delta_{\mathrm{H}} 2.38(\mathrm{t}, J=8.7 \mathrm{~Hz})$ and $1.75-0.73$ (superposed signals). The ${ }^{13} \mathrm{C}-\mathrm{NMR}$ data of $\mathbf{1 1}$ are shown in Table 2.

\subsection{Theoretical Methodology}

Theoretical studies were carried out using the Gaussian 03 software package [34]. The geometries obtained from PM3 semi-empirical calculations were used as initial models in geometry optimizations employing DFT calculations with the Pople's split valence basis set 6-31G*. BLYP exchange-correlation functional was used in DFT calculations. The optimized geometries were characterized as true minima on the potential energy surface (PES) when all harmonic frequencies were real. The electronic-nuclear energy $(E)$ of the optimized geometries was given in atomic unit (Hartree). This theoretical methodology has been efficiently employed in the study of different organic compounds, including terpenes [35-38].

The optimized geometries were used to calculate carbon chemical shifts at the same levels of theory. Values of calculated carbon chemical shift $\left(\sigma_{\mathrm{C}}\right)$ were determined in relation to the 
corresponding calculated value for tetramethylsilane $\left(\sigma_{\mathrm{C}} 187.97\right)$. Correlations between $\sigma_{\mathrm{C}}$ values and experimental carbon chemical shifts $\left(\delta_{\mathrm{C}}\right)$ were obtained using software package Origin ${ }^{\mathrm{TM}}$ Standard 7.5. The $\sigma_{\mathrm{C}}$ and $\delta_{\mathrm{C}}$ values were plotted on the $x$ and $y$ axes, respectively. The $\sigma_{\mathrm{C}} / \delta_{\mathrm{C}}$ correlation curves were given as linear fits with correlation coefficients $\left(R^{2}\right)$ and slope of the $R^{2}$ curve $(\alpha)$ furnished by the program. The BLYP/6-31G* calculations usually give satisfactory results of carbon chemical shifts, as have been obtained in previous works [39-41].

\subsection{In Vitro AChE Inhibitory Activity}

The buffers A (50 mM Tris- $\mathrm{HCl}, \mathrm{pH} 8$, containing $0.1 \mathrm{M} \mathrm{NaCl}$ and $\left.0.02 \mathrm{M} \mathrm{MgCl}_{2} \cdot 6 \mathrm{H}_{2} \mathrm{O}\right), \mathrm{B}(50 \mathrm{mM}$ Tris- $\mathrm{HCl}, \mathrm{pH} 8$, containing $0.1 \%$ bovine serum albumin), and $\mathrm{C}(50 \mathrm{mM}$ Tris- $\mathrm{HCl}, \mathrm{pH} 8)$ were prepared to study the in vitro AChE inhibitory activity. This activity was measured using a 96-well microplate reader based on an adapted Ellman's method [29,30]. The enzyme hydrolyzes the substrate acethylthiocholine. The obtained product, thiocholine, decomposes the Ellman's reagent, 5,5-dithiobis-(2-nitrobenzoic acid) (DTNB), providing 2-nitrobenzoate-5-mercaptothiocholine and 5-thio-2-nitrobenzoate, which can be detected at $405 \mathrm{~nm}$.

Volumes of acetylthiocholine iodide ( $25 \mu \mathrm{L}, 15 \mathrm{mM}$ in water), DTNB (125 $\mu \mathrm{L}, 3 \mathrm{mM}$ in buffer A), buffer $\mathrm{B}(50 \mu \mathrm{L})$, and sample $(25 \mu \mathrm{L}, 10 \mathrm{mg} / \mathrm{mL}$ in $\mathrm{MeOH}$ diluted 10-fold with buffer $\mathrm{C}$, resulting in a concentration of $1 \mathrm{mg} / \mathrm{mL}$ ) were added into each well of a 96-well microplate. Instead of adding the sample solution, a volume of $25 \mu \mathrm{L}$ of buffer $\mathrm{C}$ was employed to prepare the blank sample. The positive control was prepared under the same conditions, using physostigmine (eserine) as standard. Tests were carried out in quintuplicate. The absorbance was measured at $405 \mathrm{~nm}$ every $60 \mathrm{~s}$ by eight times using a Elisa Thermoplate microplate reader. After addition of $25 \mu \mathrm{L}$ of acetylcholinesterase solution $(0.226 \mathrm{U} / \mathrm{mL}$ in buffer $\mathrm{B})$, the absorbance was again read every $60 \mathrm{~s}$ for ten times. The increase in absorbance relative to substrate spontaneous hydrolysis was corrected by reaction rate variation before and after addition of the enzyme. The inhibition percentage was calculated by comparing the rates of the sample with the blank.

\section{Conclusions}

The hexane extract of the leaves of $M$. robusta provided seven triterpenes. The triterpenes $\mathbf{1}, \mathbf{2}$, and $\mathbf{1 1}$ were also isolated in a previous phytochemical investigation. The triterpenes $\mathbf{8}$ and $\mathbf{9}$ are described for the first time in the literature. The triterpenes $\mathbf{7}$ and $\mathbf{1 0}$ are also new compounds, but both compounds were obtained as a mixture. Hopane and seco-hopane triterpenoids are not usual in species of the family Celastraceae. The combination of experimental NMR analyses with carbon chemical shift calculations was a useful procedure for the structural determination of these hopane and friedelane triterpenes. Compounds 4, 9, and the mixture of $\mathbf{1 1}$ and sitosterol showed acetylcholinesterase inhibitory properties. These compounds present hopane- and friedelane-type skeletons, suggesting biological potential of their derivatives for Alzheimer's desease. 


\section{Supplementary Material}

Figures with liner fit curves obtained from correlations between experimental and calculated carbon chemical shifts are shown as Supplementary Material, which can be accessed at: http://www.mdpi.com/1420-3049/17/11/13439/s1. Tables with the geometric parameters and other results of all the optimized structures considered in this work are available from the authors upon request.

\section{Acknowledgements}

The authors thank the Conselho Nacional de Desenvolvimento Científico e Tecnológico (CNPq), the Fundação Coordenação de Aperfeiçoamento de Pessoal de Nível Superior (CAPES), and the Fundação de Amparo à Pesquisa do Estado de Minas Gerais (FAPEMIG) for financial support.

\section{References}

1. Chin, Y.H.; Balunas, M.J.; Chai, H.B.; Kinghorn, A.D. Drug discovery from natural sources. AAPS J. 2006, 8, E239-E253.

2. Barnes, D.E.; Yaffe, K. The projected effect of risk factor reduction on Alzheimer's disease revalence. Lancet Neurol. 2011, 10, 819-828.

3. Yang, Z.-D.; Duan, D.-Z.; Xue, W.-W.; Yao, X.-J.; Li, S. Steroidal alkaloids from Holarrhena antidysenterica as acetylcholinesterase inhibitors and the investigation for structure-activity relationships. Life Sci. 2012, 90, 929-933.

4. Dumont, M.; Wille, E.; Calingasan, N.Y.; Tampellini, D.; Williams, C.; Gouras, G.K.; Liby, K.; Sporn, M.; Nathan, C.; Flint-Beal, M.; et al. Triterpenoid CDDO-methylamide improves memory and decreases amyloid plaques in a transgenic mouse model of Alzheimer's disease. J. Neurochem. 2009, 109, 502-512.

5. Patil, S.P.; Maki, S.; Khedkar, S.A.; Rigby, A.C.; Chan, C. Withanolide A and Asiatic acidmodulate multiple targets associated with amyloid-beta precursor protein processing and amyloid-beta clearance. J. Nat. Prod. 2010, 73, 1196-1202.

6. Wilkinson, K.; Boyd, J.D.; Glicksman, M.; Moore, K.J.; El Khoury, J. A high content drug screen identifies ursolic acid as an inhibitor of amyloid beta protein interactions with its receptor CD36. J. Biol. Chem. 2011, 286, 34914-34922.

7. Zhang, X.; Wu, J.; Xia, B.; Rong, W.; Rimbach, G.; Lou, Y. Asiatic acid protects primary neurons against C2-ceramide-induced apoptosis. Eur. J. Pharmacol. 2012, 679, 51-59.

8. Corsino, J.; Silva, D.H.S.; Zanoni, M.V.B.; Bolzani, V.S.; França, S.C.; Pereira, A.M.S.; Furlan, M. Antioxidant flavan-3-ols and flavonol glycosides from Maytenus Aquifolium. Phytother. Res. 2003, 17, 913-916.

9. Yariwake, J.H.; Lanças, F.M.; Cappelaro, E.A.; Vasconcelos, E.C.; Tiberti, L.A.; Pereira, A.M.S.; França, S.C. Seasonal variability of chemical compounds (triterpenes, flavonoids, and polyphenols) from Maytenus aquifolium Mart. (Celastraceae) leaves. Braz. J. Pharmacogn. 2005, $15,162-168$. 
10. Ravelo, A.G.; Delgado-Mendes, P.; Herrera, N.; Chaves, H.; Estévez-Braun, A.; Cortes, F.; Castanys, S.; Gamarro, R. New terpenoids from Maytenus aurimacensis as MDR reversal agents in the parasite Leishmania. Bioorg. Med. Chem. 2008, 16, 1425-1430.

11. De Sousa, D.P.; Silva, M.S.; Medeiros, V.M.; Folly, M.A.B.; Tavares, J.F.; Barbosa-Filho, J.M. Alkaloid, flavonoids, and pentacyclic triterpenoids of Maytenus obtusifolia Mart. Biochem. Syst. Ecol. 2008, 36, 500-503.

12. Chabariberi, R.A.O.; Pozzi, A.C.S.; Zeraik, M.L.; Yariwake, J.H. Spectrometric determination of flavonoids from Maytenus (Celastraceae) and Passiflora (Passifloraceae) leaves and comparison with a HPLC-UV method. Braz. J. Pharmacogn. 2009, 19, 860-864.

13. Leite, J.P.V.; Braga, F.C.; Romussi, G.; Persoli, R.M.; Tabach, R.; Carlini, E.A.; Oliveira, A.B. Constituents from Maytenus ilicifolia and bioguided fractionation for gastroprotective activity. J. Braz. Chem. Soc. 2010, 21, 248-357.

14. Niero, R.; Andrade, S.F.; Cechinel Filho, V. A Review of the ethnopharmacology, phytochemistry, and pharmacology of plants of the Maytenus Genus. Curr. Pharm. Des. 2011, 17, 1851-1871.

15. Niero, R.; Moser, R.; Busato, A.C.B.; Yunes, R.A.; Reis, A.; Cechinel-Filho, V.A. Comparative chemical study of Maytenus ilicifolia Rart. Reiss and Maytenus robusta Reiss (Celastraceae). J. Biosci. 2001, 56, 158-161.

16. Niero, R.; Mafra, A.P.; Lenzi, A.C.; Cechinel-Filho, V.; Tisher, C.A.; Malheiros, A.; De Sousa, M.M.; Yunes, R.A.; Delle Monache, F. A new triterpene with antinociceptive activity from Maytenus robusta. Nat. Prod. Res. Part B 2006, 20, 1315-1320.

17. De Andrade, S.F.; Lemos, M.; Comunello, E.; Noldin, V.; Delle Monache, F.; Chechinel-Filho, V.; Niero, R. Antiulcerogenic activity of fractions and 3,15-dioxo-21 $\alpha$-hydroxyfriedelane isolated from Maytenus robusta (Celastraceae). Arch. Pharm. Res. 2008, 31, 41-46.

18. Sousa, G.F.; Ferreira, F.L.; Duarte, L.P.; Silva, G.D.F.; Messias, M.C.T.B.; Vieira Filho, S.A. Structural determination of $3 \beta, 11 \beta$-dihydroxyfriedelane from Maytenus robusta (Celastraceae) by 1D and 2D NMR. J. Chem. Res. 2012, 36, 203-205.

19. De Andrade, S.F.; Lemos, M.; Comunello, E.; Noldin, V.F.; Chechinel-Filho, V.; Niero, R. Evaluation of the antiulcerogenic activity of Maytenus robusta (Celastraceae) in different experimental ulcer models. J. Ethnopharmacol. 2007, 113, 252-257.

20. Santos, V.L.; Costa, V.B.M.; Agra, M.F.; Silva, B.A.; Batista, L.M. Pharmacological studies of ethanolic extract of Maytenus rigida Mar. (Celastraceae) in animal models. Braz. J. Pharmacogn. 2007, 17, 336-342.

21. González, A.G.; Alvarenga, N.L.; Estévez-Braun, A.; Ravelo, A.G.; Bazzocchi, I.L. Structure and absolute configuration of triterpene dimers from Maytenus scutioides. Tetrahedron 1996, 52, 9597-9608.

22. Avilla, J.; Teixidó, A.; Velásquez, N.A.; Ferro, E.; Canela, R. Insectidal activity of Maytenus species (Celastraceae) nortriterpene quinone methides against codling moth, Cydia pomonella (L.) (Lepidoptera: Tortricidae). J. Agric. Food Chem. 2001, 48, 88-92.

23. Shirota, O.; Morita, H.; Takeya, K.; Itokawa, H. Sesquiterpene pyridine alkaloids from Maytenus ilicifolia. Heterocycles 1994, 38, 383-389. 
24. González, A.G.; Tincusi, B.M.; Bazzocchi, S.L.; Tokuda, J.; Nishino, H.; Konoshima, T.; Jiménez, J.A.; Ravelo, A.G. Anti-tumor promoting effects of sesquiterpenes from Maytenus cuzcoina (Celastraceae). Bioorg. Med. Chem. 2000, 8, 1773-1778.

25. Madrigal, R.V.; Zilkowski, B.W.; Smith, C.R. Structure-activity-relationship among maytansinoides in their effect on the european corn-borer, Ostrinia-Bubilalis (Hubner) (Lipidoptera, Pyralidae). J. Chem. Ecol. 1985, 11, 501-506.

26. Kiem, P.V.; Minh, C.V.; Huong, H.T.; Nam, N.H.; Lee, J.J.; Kim, Y.H. Pentacyclic Triterpenoids from Mallotus apelta. Arch. Pharm. Res. 2004, 27, 1109-1113.

27. David, J.P.; Meira, M.; David, J.M.; Guedes, M.L.S. Triterpenos e Ferrulatos de Alquila de Maprounea guianensis. Quim. Nova 2004, 27, 62-65.

28. Ghosh, A.; Sarkar, A.; Mitra, P.; Banerji, A.; Banerji, J.; Mandal, S.; Das, M. Crystal structure and DFT calculations of 3,4-seco-lup-20(29)-en-3-oic acid isolated from Wrightia tinctoria: Stacking of supramolecular dimmers in the crystal lattice. J. Mol. Struct. 2010, 980, 7-12.

29. Ellman, G.L.; Courtney, K.D.; Andres, V.; Featherstone, R.M. A new and rapid colorimetric determination of acetylcholinesterase activity. Biochem. Pharmacol. 1961, 7, 88-95.

30. Rhee, I.K.; Van de Meent, M.; Ingkaninan, K.; Verpoorte, R. Screening for acetylcholinesterase inhibitors from Amaryllidaceae using silica gel thin-layer chromatography in combination with bioactivity staining. J. Chromatogr. A 2001, 915, 217-223.

31. Queiroga, C.L.; Silva, G.F.; Dias, P.C.; Possenti, A.; Carvalho, J.E. Evaluation of the antiulcerogenic activity of friedelan-3 $\beta$-ol and friedelin isolated from Maytenus ilicifolia (Celastraceae). J. Ethnopharmacol. 2000, 72, 465-468.

32. Salazar, G.C.M.; Silva, G.D.F.; Duarte, L.P.; Vieira-Filho, S.A.; Lula, I.S. Two epimeric friedelane triterpenes isolated from Maytenus truncata Reiss: ${ }^{1} \mathrm{H}$ and ${ }^{13} \mathrm{C}$ chemical shift assignments. Magn. Reson. Chem. 2000, 38, 977-980.

33. David, J.M.; Santos, F.A.; Guedes, M.L.S.; David, J.P. Flavonóides e triterpenos de Stigmaphyllom paralias. Quim. Nova 2003, 26, 484-487.

34. Frisch, M.J.; Trucks, G.W.; Schlegel, H.B.; Scuseria, G.E.; Robb, M.A.; Cheeseman, J.R.; Montgomery, J.A., Jr.; Vreven, T.; Kudin, K.N.; Burant, J.C.; et al. Gaussian 03, Revision B.04; Gaussian, Inc.: Pittsburgh, PA, USA, 2003.

35. Santos, F.J.L.; Alcântara, A.F.C.; Ferreira-Alves, D.L.; Piló-Veloso, D. Theoretical and experimental NMR studies of the Swern oxidation of methyl $6 \alpha, 7 \beta$-dihydroxyvouacapan-17 $\beta$ oate. Struct. Chem. 2008, 19, 625-631.

36. De Abreu, H.A.; Lagos, I.A.S.; Souza, G.P.; Piló-Veloso, D.; Duarte, H.A.; Alcântara, A.F.C. Antioxidant activity of (+)-bergenin-A phytoconstituent isolated from the bark of Sacoglottis uchi Huber (Humireaceae). Org. Biomol. Chem. 2008, 6, 2713-2718.

37. Euzébio, F.P.G.; Santos, F.J.L.; Piló-Veloso, D.; Alcântara, A.F.C.; Ruiz, A.L.G.; Carvalho, J.E.; Foglio, M.A.; Ferreira-Alves, D.L.; Fátima, A. Synthesis, Antiproliferative activity in cancer cells and theoretical studies of novel $6 \alpha, 7 \beta$-dihydroxyvouacapan-17 $\beta$-oic acid Mannich base derivatives. Bioorg. Med. Chem. 2010, 18, 8172-8177.

38. Souza, G.P.; Konzen, C.; Simões, T.R.G.; Rodrigues, B.L.; Alcântara, A.F.C.; Stumpf, H.O. Structural characterization of a new dioxamic acid derivative by experimental (FT-IR, NMR, and X-ray) analyses and theoretical (HF and DFT) investigations. J. Mol. Struct. 2012, 1016, 13-21. 
39. Alcântara, A.F.C.; Piló-Veloso, D.; Almeida, W.B.; Maltha, C.R.A.; Barbosa, L.C.A. Conformational analysis of 8-oxabicyclo[3.2.1]oct-6-en-3-one derivatives by NMR and theoretical calculations. J. Mol. Struct. 2006, 791, 180-185.

40. Pérez-Rebolledo, A.; Mendes, I.C.; Speziali, N.L.; Bertani, P.; Resende, J.M.; Alcântara, A.F.C.; Beraldo, H. N(4)-Methyl-4-nitroacetophenone thiosemicarbazone and its nickel(II) complex: Experimental and theoretical structural studies. Polyhedron 2007, 26, 1449-1458.

41. Pacheco, A.G.; Abreu, V.C.; De Abreu, H.A.; Piló-Veloso, D.; Alcântara, A.F.C. Structural analysis of aristolochic acids and aristolactams by correlations between calculated and experimental ${ }^{13} \mathrm{C}-\mathrm{NMR}$ chemical shifts. Struct. Chem. 2012, 23, 703-710.

Sample Availability: Samples of the compounds 1,2 and 9 are available from the authors.

(C) 2012 by the authors; licensee MDPI, Basel, Switzerland. This article is an open access article distributed under the terms and conditions of the Creative Commons Attribution license (http://creativecommons.org/licenses/by/3.0/). 